\title{
Be Careful and Watch Yourselves: Public Health in Jewish Teachings
}

\author{
Akiva Turner \\ PhD., JD, MPH \\ Chair and Professor, Department of Health Science, \\ Nova Southeastern University, USA
}

\begin{abstract}
Background: In this brief article, the author will focus on primary prevention as discussed in Jewish religious texts regarding halacha (Jewish law) and will briefly explore Jewish approaches to wellness and primary disease prevention. This exploration will demonstrate how Judaism views primary disease prevention. These views are consistent with medical and public health but are driven by a divine purpose.
\end{abstract}

Keywords: religion, public health, Judaism, disease prevention

\section{INTRODUCTION}

Medicine and public health have made great strides in both health promotion and disease prevention, particularly in the area of infectious diseases, as well as more limited success in the area of chronic diseases. Ideally, relying upon scientific data, public health interventions attempt to promote health and prevent disease at the population level. In doing so, public health interventions may include those designed to influence and impact individual actions and behavior change. Public health divides disease prevention into three types. First, primary prevention attempts to prevent disease in well individuals who do not yet have the disease. This would include activities such as immunization and reducing exposure to environmental toxins. Secondary prevention screens for disease in order to identify disease and reduce severity and/or complications. Tertiary prevention reduces disease impact and includes rehabilitative measures. ${ }^{1}$

In this abbreviated review, the author will focus on primary prevention, particularly as discussed in Jewish religious texts regarding halacha (Jewish law). Any discussion about the relationship between Jewish teachings with medicine, public health and science should begin with an acknowledgement that halacha, though a religious based set of law, is not anti-science. Halacha incorporates scientific medical findings when applying its laws and teachings, including concepts of risk and benefit. ${ }^{2}$ Within this context, this article will briefly explore Jewish approaches to wellness and primary disease prevention. This exploration will demonstrate how Judaism views primary disease prevention and how these views are consistent with medical and public health. In doing so, I am not suggesting a materialistic reason or function for the existence of these concepts in Judaism. To do so would separate Judaism from its religious source. I am, however, suggesting that in Judaism disease prevention and health promotion may be viewed as a connection with the Divine. Indeed, in Judaism caring for the body is necessary so that the Jew is capable of serving the Divine. The Jew does not own his or her body. The physical body, inhabited by the soul, is considered to be on loan from the Divine, and thus one is obligated to care for it, not damage it, and take actions to protect it. ${ }^{2}$ 
There is a general overall directive in halacha to protect one's life and the lives of others. The Jewish directive is called pikuakh nefesh (saving a life), and it is an important mitzvah (obligation/ connection to the Divine). It includes saving one's own life as well as the life of another. It is so central to Judaism that if necessary to save a life, one is required to violate the Sabbath, eat forbidden foods, and eat on the biblical fast day of Yom Kippur. ${ }^{3}$ There are only a few biblical laws that cannot be violated to save a life such as prohibitions against idolatry and certain sexual relations. ${ }^{4}$

The Torah describes the Divine as a rofeh (healer). "If you will (accept upon yourselves)," the Torah advises, "to listen to the voice of G-d, your G-d, and you will (actually) perform (the commandments) which are just in His eyes, and you observe His commandments (with precision), and observe all His statutes (which defy logic) -then all the sicknesses that I have placed upon Egypt will not place upon you, for I am G-d, your Healer". ${ }^{5}$ According to one commentator "for I am G-d you healer" means the following:

Medicine has two general aspects: cure and prevention. At first glance, the accomplishment of the physician in curing the sick seems more impressive by its dramatic results, than preventative medicine......In truth, however, it is better to be certain of immunity to sickness. The latter is the way of $G$-d, as the verse states: "All the sickness...I will not place upon you, for I am $G$-d, your Healer" 6

There is always some uncertainty if a person is worthy enough to rely upon some Divine intervention to protect one's health, and thus one needs to engage in acts to protect one's own health and the health of others. For example, according to the Torah, one should "be careful and watch" oneself and "greatly heed" ones soul, and "look after yourselves very well." 7,8

In the $20^{\text {th }}$ century, the Lubavitcher Rebbe wrote, "Preventive medicine has been employed by distinguished Jewish greats and leaders on a regular basis." For example, the well-known physician and Rabbi, Maimonides or Rambam, who lived in the 12th and 13th centuries, wrote that a person can only serve the Divine if the person is healthy and has well-being. ${ }^{9}$ Maimonides also served as the physician to the Sultan of Egypt who was known to always be healthy and not afflicted with illness. The Sultan was concerned that he did not know if Maimonides was a skilled physician since Maimonides had not had the opportunity to treat or cure the Sultan given the Sultan's excellent health. Emphasizing that the Divine is the true great physician, Maimonides told the Sultan that the ability to prevent illness is a greater proof of a physician's skill than the ability to cure. ${ }^{10}$

Specifically, halacha pointedly addresses the avoidance and prevention of communicable diseases. In the Shulchan Aruch, the authoritative code of Jewish Law, Rabbi Moshe Isserles ("Rema") ruled that when a plague breaks out in a city, the city's residents should run away to evade infection and death. ${ }^{11}$ Though not a physical disease, the Torah also describes an infectious spiritual disease that requires isolation. The disease is called tzaraat, often erroneously translated as leprosy. Though a spiritually caused affliction, tzaraat would manifest itself on one's skin, and even on clothing, belongings, and one's house. Part of the treatment was for the person to be excluded from the camp. ${ }^{12}$

The Torah also instructs on hygiene and environmental exposures. The Torah instructs that latrines be made away from military camps and that excrement be covered. ${ }^{13}$ It also sets a distance that a tannery, carcass, or grave can be from a city and a scholar is directed to live in a city with a public bath and an outhouse. 14 A Jew is permitted on the Sabbath to wash one's face, hands, and feet-something done daily--for the sake of the Divine. ${ }^{15}$ The Jew must also wash his or hands after other specific activities, including after urinating or defecation. ${ }^{16}$ 
There is a story about the first century sage Hillel that describes well the importance of cleanliness:

Hillel the Elder, who, at the time that he was departing from his students, would walk with them. They said to him, "Rabbi, where are you walking to?" He said to them, "To fulfill a commandment!" They said to him, "And what commandment is this?" He said to them, "To bathe in the bathhouse." They said to him: "But is this really a commandment?" He said to them: "Yes. Just like regarding the statues of kings, that are set up in the theaters and the circuses, the one who is appointed over them bathes them and scrubs them, and they give him sustenance, and furthermore, he attains status with the leaders of the kingdom; I, who was created in the [Divine] Image and Form, as it is written, "For in the Image of G-d He made Man, "even more so!..." 17

The Torah also emphasizes safety measures to prevent injury. For example, Jews are obligated to build a guardrail around the roof of a newly built home lest someone fall. ${ }^{18}$ A roof may also double as a porch, and when it does, a railing is necessary to prevent someone from falling. By analogy, this obligation has been applied to other behaviors and activities as well that are necessary to protect others including vaccinations. ${ }^{2}$ Even more directly, the Torah directs a Jew not to stand idly by the blood of a neighbor. ${ }^{19}$ Given this, if one can prevent death without great risk to oneself and neglects to do so, one has transgressed a Torah commandment.

In conclusion, in various areas of Torah, there is an emphasis on private and public interventions and behaviors directed toward protecting one's health and preventing disease. These interventions and behaviors are considered a religious obligation. Though their outcome may be reduced morbidity and mortality, the essential reason for this reduction is so that the individual Jew may serve the Divine

Funding details: None

Acknowledgements: None

Conflict of interests: Authors declare that there is no conflict of interest

\section{References}

Gordis L. Epidemiology. Philadelphia: Elsevier Saunders. 2014.

Turner A. Jewish Decisions About Childhood Vaccinations: The Unification of Medicine with Religion. Paediatrics and Health. 2017; 5:1.

Tractate Pesachim 25a, Shottstein Edition.

Tractate Yoma 85b and Tractate Sanhedrin 74a, Shottstein Edition.

Exodus 15:26, The Slager Edition.

Rabbi Miller Chaim commentary to Exodus 15:26, The Slager Edition.

Brody S. Does Jewish law mandate vaccinations? The Jerusalem Post. 2013. https://www.jpost.com/JewishWorld/Judaism/Does-Jewish-law-mandate-vaccinations-326531

Deuteronomy 4:15, The Slager Edition.

Mishneh Torah Hilchot Deot, 3, Eliyahu Touger Edition.

Yalkut Lekach Tov, Shemot and BeShalach.

Shulchan Aruch, Yoreh De'ah 116:5.

Numbers 5:1-4, The Slager Edition.

Deuteronomy 23: 13-15, The Slager Edition. 
Tractate Bava Basra 25a and Tractate Sanhedrin 17b, Shottsein Edition.

Tractate Shabbat 50b, Shottstein Edition.

Shulchan Aruch, Orach Chayim, 4:18.

Vayikrah Rabbah 34:3, https://www.sefaria.org/Vayikra_Rabbah.34.3?vhe=Midrash_Rabbah_-TE\&ven=Sefaria_Community Translation\&lang=bi\&with=all\&lang2=en

Devarim 22:8, The Gutnick Edition.

Leviticus 19:16, The Gutnick Edition 